\title{
Multi-Decadal Change in Reef-Scale Production and Calcification Associated With Recent Disturbances on a Lizard Island Reef Flat
}

\section{OPEN ACCESS}

Edited by:

Hajime Kayanne,

The University of Tokyo, Japan

Reviewed by:

Juan Pablo Carricart-Ganivet,

National Autonomous University

of Mexico, Mexico

Aldo Cróquer:

Simón Bolívar University, Venezuela

*Correspondence:

Chiara Pisapia

chiara.pisapia@csun.edu

Specialty section:

This article was submitted to

Coral Reef Research,

a section of the journal

Frontiers in Marine Science

Received: 29 March 2019

Accepted: 29 August 2019

Published: 11 September 2019

Citation:

Pisapia C, Hochberg EJ and Carpenter R (2019) Multi-Decadal Change in Reef-Scale Production and Calcification Associated With Recent Disturbances on a Lizard Island Reef Flat.

Front. Mar. Sci. 6:575. doi: 10.3389/fmars.2019.00575

\author{
Chiara Pisapia ${ }^{1 *}$, Eric Jeremy Hochberg ${ }^{2}$ and Robert Carpenter ${ }^{1}$ \\ ${ }^{1}$ Department of Biology, California State University, Northridge, Los Angeles, CA, United States, ${ }^{2}$ Bermuda Institute \\ of Ocean Sciences, St. George's, Bermuda
}

Climate change is threatening the persistence of coral reef ecosystems resulting in both chronic and acute impacts which include higher frequency and severity of cyclones, warming sea surface temperatures, and ocean acidification. This study measured net ecosystem primary production (NEP) and net ecosystem calcification (NEC) on a reef flat after the most severe El Nino-driven mass bleaching event on Australia's Great Barrier Reef (GBR) in 2016 and again in 2018 after another consecutive bleaching event in 2017. Our results indicate temporal changes in reef metabolism likely as result of both the continuing press disturbance of ocean acidification and severe pulse disturbances (cyclones and bleaching events). In 2016, NEP was within the range of values reported in past studies, however, it declined in 2018. NEC over a 12-h period was lower in 2016 than 2018; but when compared with past studies there was a severe decline in daytime net calcification from 2008-2009, to 2016 followed by an increase in 2018 (but still NEC remained lower than values reported in 2008-2009). Conversely, nighttime net calcification was similar to that reported in 2009 indicating nighttime dissolution did not increase over the past decade. Overall coral cover remained stable following recent disturbances, however, algal turf was the dominant benthic component on the reef flat, while calcifiers (corals and calcified algae) were minor components ( $<20 \%$ of total benthic cover). This study documented temporal changes in community function following major pulse disturbances (bleaching events and cyclones) within the context of ongoing $\mathrm{OA}$ at the same location over the last decade. Repeated pulse disturbances could jeopardize the persistence of the reef flat as a net calcifying entity, with the potential for cascading effects on other ecosystem services.

Keywords: NEC, NEP, bleaching, cyclone, ocean acidification, Lizard Island, great barrier reef

\section{INTRODUCTION}

Coral reefs are highly dynamic ecosystems that have developed under a wide range of disturbances operating at different spatial and temporal scales (Nyström and Folke, 2001). Therefore, disturbance has a large role in regulating reef community structure. The effects of disturbance on reef ecosystem function, either directly through modification of the physical/chemical 
environment, or indirectly through altered community structure, are less studied. Two common metrics of ecosystem function (measured in the field) are net ecosystem primary production (NEP) and net ecosystem calcification (NEC) (Andersson and Mackenzie, 2004). NEP/NEC typically are measured over sections (100 s of meters) of reefs (Kinsey, 1979; Barnes, 1983; Odum and Odum, 1955), thereby integrating specific community structure/function relationships over a larger scale. While NEP/NEC have been quantified at a diversity of coral reef locations (Kinsey, 1979; Shamberger et al., 2011; Albright et al., 2015; Takeshita et al., 2016), repeated measurements over time at a single location are rare. As a result, we have little understanding of: 1) how reef community structure affects function, and 2) how disturbances affect reef function. Disturbances can act at a variety of spatial scales and, together with other processes (e.g., competition, predation), can create spatial variability in community structure. It is likely that many coral reefs are a mosaic of patches at different stages of recovery depending on the frequency and intensity of disturbances (Done et al., 1991; Connell et al., 1997). The long-term trajectories for coral abundance over the past several decades on reefs throughout the tropics are consistently downward (Edmunds, 2002; Gardner et al., 2003; De'ath et al., 2012; Pisapia et al., 2016), raising concern that coral reef ecosystems are becoming dominated increasingly by non-calcifying taxa and may cease to exist as intact, calcified entities in the future (Kuffner et al., 2008; Norström et al., 2009). To better understand responses of coral reefs to environmental changes, most of the focus has been allocated to investigating changes in live coral cover and community composition (Gardner et al., 2003; Halford et al., 2004; De'ath et al., 2012), while the current understanding of the consequences of disturbance for community function is more limited.

Primary production and respiration are the major metabolic processes by which mass and energy move through any community or ecosystem (Hatcher, 1997), therefore measurements of these processes are fundamental to understanding the responses of ecosystems to disturbance. NEP is the net rate of photosynthetic carbon fixation into organic matter, and together with nutrient assimilation, represents the capacity of a community to capture energy into the production of new biomass from inorganic precursors. Respiration (R) represents the rate of decomposition of organic matter and is a measure of the metabolic demand of a community of organisms for biochemical energy. In coral reef ecosystems, an equally important process to NEP and R, is NEC, which is the gross rate at which $\mathrm{CaCO}_{3}$ is incorporated into organism skeletons, less the rate of dissolution which is the physical and chemical conversion of carbonate skeletons to sediments and carbonate ions, respectively. Positive NEC indicates that the biogenic structure is accreting calcium carbonate and that calcifying organisms such as foraminifera, calcareous algae and reef-building scleractinian corals, are producing $\mathrm{CaCO}_{3}$ faster than the physical, chemical, and bioerosive processes are removing it, thus maintaining reef accretion and growth.

Changes in $\mathrm{CO}_{2}$ concentration can affect both NEP and NEC (Melillo et al., 1993; Kleypas et al., 1999; Nemani et al., 2003;
Albright et al., 2016). In the ocean, increased $\mathrm{CO}_{2}$ drives declines in the saturation state of calcium carbonate $(\Omega)$, including aragonite which is the dominant biogenic form of $\mathrm{CaCO}_{3}$ secreted by corals [ $\Omega$ has declined from 4.6 to 4.0 in the last century (Kleypas et al., 1999)] and since calcification is correlated positively with $\Omega$ (Smith and Buddemeier, 1992), there is concern that reef communities may reach a critical threshold beyond which their ability to calcify will be compromised (Gattuso et al., 1999). Effects of $\mathrm{pCO}_{2}$ on coral reef NEP are less wellunderstood (Langdon et al., 2003) but there is the potential for a "fertilization" effect by increased concentrations of dissolved inorganic carbon (DIC) for photosynthesis, especially by freeliving algae. This could tip competitive outcomes between corals and algae in favor of faster growing macroalgae and maintain or even increase community NEP even though corals decrease in abundance. Similarly, the increase in seawater temperature (SST) may affect NEC and NEP because rising SST often results in coral bleaching, which involves loss of symbiotic algae that normally are the primary source of energy for corals (Hoegh-Guldberg, 1999; Hughes et al., 2017b) and thus may cause severe mortality of calcifiers with subsequent declines in NEP and NEC (Kayanne et al., 2005; DeCarlo et al., 2017).

The majority of studies have investigated species-specific responses to bleaching and/or ocean acidification (Cooper et al., 2008; De'ath et al., 2009; Comeau et al., 2013, 2016), but see (Dove et al., 2013; Silverman et al., 2014) and have demonstrated that some species are more susceptible to bleaching than others and that effects of $\mathrm{pCO}_{2}$ on calcification also is species-specific (Comeau et al., 2013) with the subsequent consequences at community and ecosystem levels dependent on the relative abundances of sensitive and less sensitive taxa (Dove et al., 2013). However, it is extremely difficult to extend species-level effects to effects on the wider community because responses of organisms vary among taxa and among life stages (Russell et al., 2011; Gaylord et al., 2015; Edmunds et al., 2016) and may depend on the responses non-biotic components of the reef [i.e., sediments and carbonate pavement (Comeau et al., 2015, 2016)].

The present study measured NEP and NEC following the 2016 and 2017 mass-bleaching events at Lizard Island in the northern section of the Australia Great Barrier Reef (GBR) where historical data on NEP and NEC are available (Limer, 1976; Kinsey, 1979; Silverman et al., 2014). In 2014 and 2015, Lizard Island was also affected by two consecutive cyclones (Madin et al., 2018). Calcification rates were quantified first at Lizard Island in 1975-1976 using the alkalinity anomaly technique (Limer, 1976; Kinsey, 1979). Three decades later in 2008-2009 the same measurements were repeated at the same reef sites and documented large reductions in net calcification (44\% reduction) over that 4-decade period, primarily due to a threefold increase in nighttime dissolution rates (Silverman et al., 2014). When comparing different studies, caution should be employed because different methods may introduce variability (McMahon et al., 2019). Here we report further changes in NEP and NEC likely associated with both the ongoing press disturbance of ocean acidification, and following four severe pulse disturbances (two bleaching events and two cyclones) to the same reef where the previous measurements were made. Since distinct zones of NEP 
and NEC have been identified on coral reefs (Barnes, 1983), we also quantified NEC in two different zones from the reef crest to the reef flat. We expected to find a decline in NEC due to reduced live coral cover, while we predicted that NEP would increase due to more abundant benthic algae which often increase in biomass and percent cover following high coral mortality (Hughes et al., 2007).

\section{MATERIALS AND METHODS}

\section{Benthic Community Productivity and Calcification}

This study was conducted at Lizard Island $\left(14^{\circ} 41^{\prime} \mathrm{S}, 14^{\circ} 528^{\prime} \mathrm{E}\right)$ in the northern section of the Australia's GBR. The study site was on the reef flat between Bird Island and South Island, which is exposed to the southeasterly trade winds that generate consistent wave-driven flow over the reef (Figure 1).

NEP and NEC were measured in 2016 and 2018 (in the austral spring similar to previous measurements) using a Lagrangian approach. This method involves measuring total alkalinity $\left(\mathrm{A}_{\mathrm{T}}\right)$, flow, water depth, and dissolved oxygen (DO) of water at upstream and downstream locations on the reef flat community. This approach can be used on reefs that experience unidirectional flow of water across the reef flat (Langdon et al., 2010). The positions of the up- and downstream stations were established by deploying drogues and following them for repeated tracks under different tidal conditions. The distance between the established up- and downstream stations was $273 \mathrm{~m}$.

The instruments deployed at both the up- and downstream moorings consisted of a Nortek (Boston, MA, United States) Aquadopp acoustic doppler profilers (ADP) to measure 3-D velocity and water depth, and optode oxygen sensors $\left(\mathrm{MiniDO}_{2} \mathrm{~T}\right.$, PME, Vista, CA, United States). At the downstream location, a $2 \pi$ PAR sensor (Biospherical Instruments, San Diego, CA, United States) connected to a SeaBird 16Plus CTD (Bellevue, WA, United States) recorded PAR each minute in 2016; while in 2018 an Odyssey $2 \pi$ PAR sensor (Dataflow Systems Ltd., Christchurch, New Zealand) was used. The ADPs measured water flow in $10-\mathrm{cm}$ bins from $20 \mathrm{~cm}$ above the benthos to the water surface at 1-min intervals. The oxygen sensors have an accuracy of $10 \mu \mathrm{mol} / \mathrm{L}$ and were within factory calibrations. Prior to deployment, the $\mathrm{O}_{2}$ sensors were moored together overnight to provide cross-calibrations. The sensors recorded oxygen each minute over the course of the deployment. On two occasions (Day 4 and 6 of the deployment) water samples for Winkler determination of $\mathrm{O}_{2}$ were taken adjacent to each of the $\mathrm{O}_{2}$ sensors using a Niskin (General Oceanic, Miami, FL, United States) bottle. Water samples were fixed immediately after collection (in the boat) and Winkler titrations were performed immediately after return to the lab using a Metrohm (Riverview, FL, United States) Dosimat manual titrator. Instruments were deployed on the transect from September 4-10 in 2016 and from September 12-17 in 2018 resulting in five complete days of measurements of NEP/NEC for each time period.

NEC was estimated using the $\mathrm{A}_{\mathrm{T}}$ anomaly method (Smith and Kinsey, 1978). In 2016 replicate seawater samples were taken at both the up- and downstream ends of the transect in the morning (1000 h local time) and afternoon (1600 h local time). Water samples were collected in $125-\mathrm{mL}$ bottles filled below the water surface and immediately poisoned with $200 \mu \mathrm{L} \mathrm{HgCl}_{2}$ to inhibit biological activity. $\mathrm{A}_{\mathrm{T}}$ was determined by potentiometric titration using standard protocols (SOP6A, Dickson et al., 2007). In 2018, $\mathrm{A}_{\mathrm{T}}$ was measured in two, replicate seawater samples taken at each of the up- and downstream ends of the transect 4 times each day $(0900,1300,1500,1800 \mathrm{~h}$ local time). For one 24-h period (September 13, 2018) water samples were collected every $2 \mathrm{~h}$ at both the up- and downstream locations. Water samples were collected in 125-mL amber glass bottles filled at $\sim 100 \mathrm{~cm}$ above the substratum and were analyzed for $\mathrm{A}_{\mathrm{T}}$ within $24 \mathrm{~h}$ by potentiometric titration using standard protocols (SOP6a, Dickson et al., 2007). Accuracy for all titrations were determined using certified reference materials (from A. Dickson) and typically was $\sim 2-3 \mu \mathrm{mol} \mathrm{kg}{ }^{-1}$. To compare NEC measurements to previous estimates (Limer, 1976; Kinsey, 1979; Silverman et al., 2014) and investigate spatial variation in NEC across reef zones, in 2018 four replicate water samples also were collected from the open ocean in front of the studied reef flat and analyzed for $\mathrm{A}_{\mathrm{T}}$ using the above protocol.

To facilitate a comparison of our metabolism measurements with those made previously, we also quantified benthic community composition on the reef flat from individual images and photomosaics. In 2016, photomosaics $(10 \mathrm{~m} \times 10 \mathrm{~m})$ were made at each the two endpoints of the transect from 4001400 overlapping digital photos. To estimate spatial variation in benthic cover across the reef flat, seven additional sites were surveyed on the reef flat with the same technique (Figure 1). In 2018, > 800 overlapping photos were taken along the whole $273 \mathrm{~m}$ transect to better estimate community structure and capture temporal changes in benthic cover. Photos were analyzed using Agisoft PhotoScan Pro (Agisoft LLC) software and Coral Net (Coralnet.ucsd.edu). Relative abundances of the major benthic taxa were estimated by standard point counting methods, with 1000 points laid on an equidistant grid across each mosaic. Since it was not possible to create a mosaic representing the whole metabolic transect, cover of benthic taxa in 2018 was estimated with 100 points across each photo. The functional group underlying each point was identified as one of the following: live coral, crustose coralline algae, other calcified algae, macroalgae, algal turf, sediment, and other.

\section{Calculations}

NEP was calculated using the following:

$$
\mathrm{NEP}(\mathrm{R})=\frac{\left(\mathrm{DO}_{\mathrm{DN}}-\mathrm{DO}_{\mathrm{UP}}\right.}{\mathrm{L}} \frac{\left(\mathrm{U}_{\mathrm{UP}}+\mathrm{U}_{\mathrm{DN}} \mathrm{H}_{\mathrm{DN}}\right)}{2}-\mathrm{J}_{\text {air }- \text { sea }}
$$

where DO is dissolved oxygen concentration ( $\mu \mathrm{mol} / \mathrm{L})$, UP is the upstream mooring, $\mathrm{DN}$ is the downstream location, $\mathrm{H}$ is average water depth $(\mathrm{m}), \mathrm{U}$ is the depth-averaged vector-rotated velocity along the axis of the transect $(\mathrm{m} / \mathrm{s}), \mathrm{L}$ is the distance between the moorings (m), and $J$ is the air-sea flux. This assumes that mean depth-integrated Lagrangian transport along the transect path is $\left(\mathrm{U}_{U P} \mathrm{H}_{U P}+\mathrm{U}_{D N} \mathrm{H}_{D N}\right) / 2$. Respiration rates $(\mathrm{R})$ were obtained from the same equation using the data collected each night. 


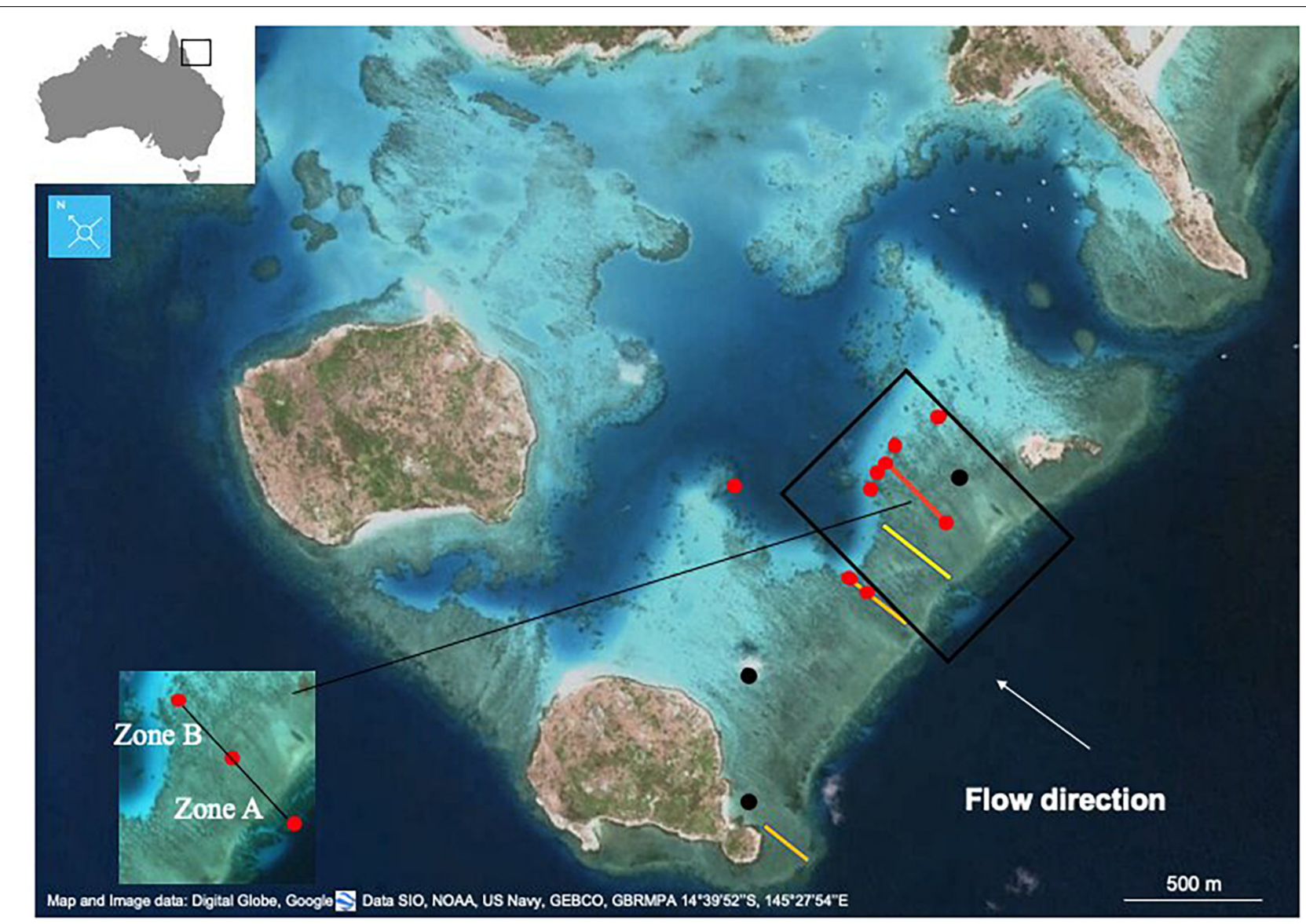

FIGURE 1 | Study transect at Lizard Island (red line). Benthic cover in 2016 was measured at the two endpoints of the transect (red line) and in other sites (red dots), while in 2018 it was measured along the entire length of the transect (red line). In 2018 NEC was calculated in different reef zones: reef crest (Zone A), and on the reef flat between the upstream and downstream moorings (Zone B). During the 1970s measurements were made along the transect in yellow (Limer, 1976) (Kinsey, 1979). In 2008-2009 NEC was measured at SIRM02 (2008) and SIRM03 (2009) (the two black dots) (Silverman et al., 2014). Past benthic community surveys were conducted along the two transects in orange (Pichon and Morrissey, 1981) and (Silverman et al., 2014) in 2008-2009.

Air-sea flux $(J)$ is:

$$
\mathrm{J}_{\mathrm{air}-\mathrm{sea}}=\mathrm{K}_{\mathrm{o}_{2}}\left(\mathrm{DO}_{\text {sat }}-\mathrm{O}_{2}^{\text {water }}\right)
$$

where $\mathrm{O}_{2}^{\text {water }}$ is the concentration of oxygen in the water, $\mathrm{DO}_{\text {sat }}$ is the saturation oxygen concentration and $K_{O_{2}}$ is the gas transfer coefficient. The saturation of oxygen at the air-water interface, $\mathrm{DO}_{\text {sat }}$ is computed from Henry's Law (Benson and Krause, 1984). NEP and R were calculated for each minute and then averaged to give hourly values for each 24-period. The sum of hourly values for each day then was used to calculate daily averages of NEP. Daily gross ecosystem primary production (GEP) was calculated as the sum of daily NEP and R for each day.

Calcification (NEC) was calculated using the $A_{T}$ anomaly method (Smith and Kinsey, 1978), which uses the change in $A_{T}$ as water flows across the reef and the stoichiometric relationship between alkalinity depletion/addition and calcification/dissolution to calculate NEC. Total alkalinity decreases by 2 moles for each mole of $\mathrm{CaCO}_{3}$ precipitated. Total alkalinity increases by the same ratio as a result of dissolution of $\mathrm{CaCO}_{3}$. NEC was calculated using the $\mathrm{A}_{\mathrm{T}}$ anomaly method (from the discrete water samples) as:

$$
\mathrm{NEC}=\left[\left(\Delta \mathrm{A}_{\mathrm{T}} / 2\right)^{*} \rho\right]^{*}\left(\mathrm{H}^{*} \mathrm{U}\right) / \mathrm{D}
$$

where: NEC is the net calcification rate $\left(\mathrm{mmol} \mathrm{CaCO}_{3}\right.$ $\left.\mathrm{m}^{-2} \mathrm{~d}^{-1}\right), \Delta \mathrm{A}_{\mathrm{T}}$ is the difference between $\mathrm{A}_{\mathrm{T}}$ upstream and $\mathrm{A}_{\mathrm{T}}$ downstream $(\mu \mathrm{mol} / \mathrm{kg})$, or between oceanic water and upstream/downstream reef flat locations, $\rho$ is the seawater density $\left(1024 \mathrm{~kg} / \mathrm{m}^{3}\right), \mathrm{H}$ is the average water depth across the transect $(\mathrm{m}), \mathrm{U}$ is the average hourly water velocity between the moorings $(\mathrm{m} / \mathrm{s})$, and $\mathrm{D}$ is the transect length between upstream and downstream locations (m). To compare measurements in 2018 with past values (Silverman et al., 2014), NEC also was calculated from the difference between $\mathrm{A}_{\mathrm{T}}$ measured in the open water off the reef and the reef flat upstream mooring to quantify NEC rates of the reef crest and seaward reef flat (Figure 1). Oceanic water samples were collected within $10 \mathrm{~m}$ of the reef crest and it was assumed that flow speed and depth were the same as measured at the upstream mooring. It was also assumed that $\mathrm{A}_{\mathrm{T}}$ collected in open ocean was constant over time (Andersson et al., 2014). 
All rates were converted to a 12 -h day by summation of the mean hourly rates.

\section{RESULTS}

During the 6 days of deployment in 2016 the sky was very cloudy to clear with occasional heavy rain, while in 2018 the sky was clear during the whole study. Water temperature averaged $25.7 \pm 0.01^{\circ} \mathrm{C}$ during both sampling periods.

In 2016, photosynthetically active radiation (PAR) in situ (at 3-m depth) averaged $541 \pm 45 \mu \mathrm{mol}$ quanta $\mathrm{m}^{-2} \mathrm{~s}^{-1}$ during the day (Figure 2A). In 2018, at the same location, PAR was slightly lower averaging $490 \pm 41.3 \mu \mathrm{mol}$ quanta $\mathrm{m}^{-2} \mathrm{~s}^{-1}$ during the day (Figure 2B). Mean ( \pm SE) upstream flow speeds ranged from $0.22 \pm 0.01 \mathrm{~m} / \mathrm{s}$ on the first day and declined to $0.12 \pm 0.01 \mathrm{~m} / \mathrm{s}$ during the last 2 days of deployment of 2016. During the measurement period, flow was higher upstream than downstream with large variation within days due to tidal height changes, with higher flows at high tides. Over the 6 days, mean flow velocity $( \pm$ SE) upstream was $0.22 \pm 0.01 \mathrm{~m} / \mathrm{s}$ and $0.13 \pm 0.01 \mathrm{~m} / \mathrm{s}$ downstream. In 2018, flow was strongly swelldriven with a strong tidal signal. Mean ( \pm SE) flow at the upstream mooring was $0.17 \pm 0.01 \mathrm{~m} / \mathrm{s}$ and $0.10 \pm 0.01 \mathrm{~m} / \mathrm{s}$ downstream. Dissolved oxygen increased during the day and declined at night in response to photosynthesis and respiration and water exchange with the open ocean. Average depth across

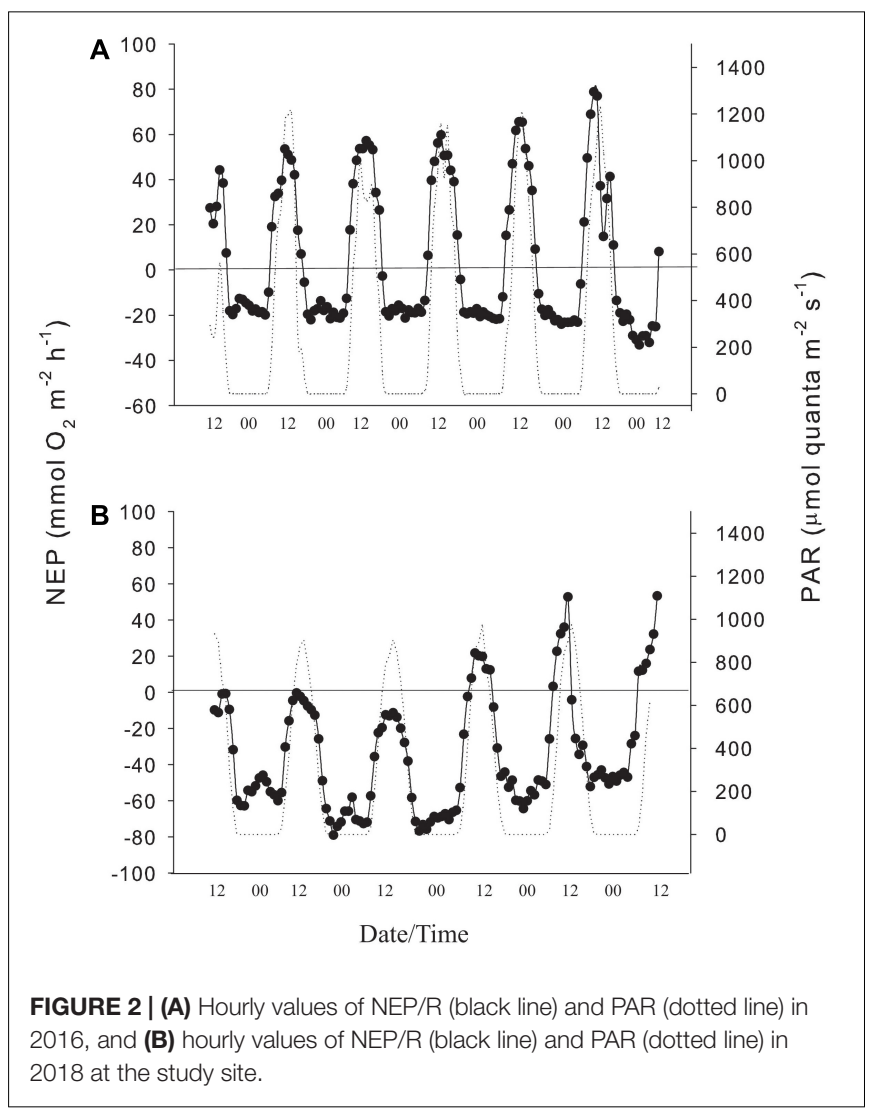

the transect was $2.3 \pm 0.02 \mathrm{~m}$ with an average tidal range of $1.3 \pm 0.06 \mathrm{~m}$ during the measurement period.

NEP showed a clear diurnal pattern with maximum rates near the solar zenith. In 2016, NEP ranged from -19.5 to $119.7 \mathrm{mmol}$ $\mathrm{O}_{2} \mathrm{~m}^{-2} \mathrm{~h}^{-1}$ with a mean $( \pm \mathrm{SE})$ of $36.2 \pm 3.33 \mathrm{mmol} \mathrm{O}_{2}$ $\mathrm{m}^{-2} \mathrm{~h}^{-1}$. Nighttime respiration ranged from 8.1 to $33.1 \mathrm{mmol}$ $\mathrm{O}_{2} \mathrm{~m}^{-2} \mathrm{~h}^{-1}$ and averaged $-20.3 \pm 1.36 \mathrm{mmol} \mathrm{O}_{2} \mathrm{~m}^{-2} \mathrm{~h}^{-1}$ (Figure 2A). GEP, calculated from NEP and R in 2016 was similar to values reported in 1970s for the same location (Table 1). NEP values in 2018 were lower than measured in 2016 for the same reef flat (Figure 2B). In 2018, NEP ranged from to -71.4 to $52.8 \mathrm{mmol}$ $\mathrm{O}_{2} \mathrm{~m}^{-2} \mathrm{~h}^{-1}$ and averaged $-17.4 \pm 3.4 \mathrm{mmol} \mathrm{O}_{2} \mathrm{~m}^{-2} \mathrm{~h}^{-1}$ while nighttime respiration ranged from -23.9 to $-79.01 \mathrm{mmol} \mathrm{O}_{2}$ $\mathrm{m}^{-2} \mathrm{~h}^{-1}$ and averaged $-53.6 \pm 2.8 \mathrm{mmol} \mathrm{O}_{2} \mathrm{~m}^{-2} \mathrm{~h}^{-1}$. NEP was $<20 \mathrm{mmol} \mathrm{O}_{2} \mathrm{~m}^{-2} \mathrm{~h}^{-1}$ during the first 3 days of the deployment and increased to values similar to those measured in 2016 during the last 3 days (Figure 2 and Table 1 ).

In 2016, NEC for the reef flat was consistent over the measurement period, ranging from -6.76 to $22.8 \mathrm{mmol} \mathrm{CaCO}_{3}$ $\mathrm{m}^{-2} \mathrm{~h}^{-1}$ (Figure 3) with a mean $( \pm \mathrm{SE}$ ) of $10.6 \pm 2.44 \mathrm{mmol}$ $\mathrm{CaCO}_{3} \mathrm{~m}^{-2} \mathrm{~h}^{-1}$. In 2018, NEC on the reef flat (Zone B, Figure 1) ranged from 12.5 to $57.6 \mathrm{mmol} \mathrm{CaCO}_{3} \mathrm{~m}^{-2} \mathrm{~h}^{-1}$ with a mean $( \pm \mathrm{SE})$ of $34.8 \pm 18.6 \mathrm{mmol} \mathrm{CaCO}_{3} \mathrm{~m}^{-2} \mathrm{~d}^{-1}$. Nighttime NEC of the reef flat in 2018 had a mean $( \pm \mathrm{SE})$ of $12.3 \pm 9.93 \mathrm{mmol}$ $\mathrm{CaCO}_{3} \mathrm{~m}^{-2} \mathrm{~d}^{-1}$ (Figure 3 and Table 2).

In 2018, there were distinct differences in NEC among the two reef zones (Figure 3). NEC was lower on the reef crest and higher on the reef flat (Figure 3). Dissolution on the reef crest (Zone A) was higher than calcification during both night and day. Daytime NEC of the reef crest ranged from 1.45 to $-21.6 \mathrm{mmol} \mathrm{CaCO}_{3} \mathrm{~m}^{-2} \mathrm{~h}^{-1}$ and averaged $-29.1 \pm 20.9 \mathrm{mmol}$ $\mathrm{CaCO}_{3} \mathrm{~m}^{-2} \mathrm{~d}^{-1}$, while nighttime NEC in this zone ranged from -1.2 to $-46.05 \mathrm{mmol} \mathrm{CaCO}_{3} \mathrm{~m}^{-2} \mathrm{~h}^{-1}$ with a mean $( \pm \mathrm{SE}$ ) of $-49.6 \pm 106.01 \mathrm{mmol} \mathrm{CaCO}_{3} \mathrm{~m}^{-2} \mathrm{~d}^{-1}$. Nighttime NEC over the entire reef (reef crest and flat) ranged from 7.02 to $-38.6 \mathrm{mmol}$ $\mathrm{CaCO}_{3} \mathrm{~m}^{-2} \mathrm{~h}^{-1}$ with a mean $( \pm \mathrm{SE})$ of $-38.4 \pm 86.7 \mathrm{mmol}$ $\mathrm{CaCO}_{3} \mathrm{~m}^{-2} \mathrm{~d}^{-1}$ and was within the range of values measured previously. The negative NEC values observed at night indicated nighttime net dissolution. Importantly, daytime NEC also was lower [ranging from 16.6 to $-25.3 \mathrm{mmol} \mathrm{CaCO}_{3} \mathrm{~m}^{-2} \mathrm{~h}^{-1}$ with a mean $( \pm \mathrm{SE})$ of $5.32 \pm 23.04 \mathrm{mmol} \mathrm{CaCO}_{3} \mathrm{~m}^{-2} \mathrm{~d}^{-1}$ ] than values reported in 2008-2009 measured in the same reef zone, suggesting a decline in net calcification and a potential increase in dissolution (Tables 1, 2).

The sites measured in 2016, and in particular the two endpoints of the metabolic transect, were dominated by algal turf and sand with mean ( \pm SE) percent covers of $67 \pm 4.66$ and $21.6 \pm 3.81$ respectively (Figure 1 and Table 1). Macroalgal percent cover was only $2.07 \pm 1.73$, and importantly, calcified organisms such as corals and crustose coralline algae were only minor components, with percent covers of $2.6 \pm 1.86$ and $4.2 \pm 2.37$ respectively (Table $\mathbf{1}$ ). Community structure in 2018 was measured along the whole transect and was overall similar to 2016. Community structure was again dominated by algal turf and sand $43.7 \pm 1.4$ and $29.1 \pm 1.8$ respectively. Dead coral skeletons covered with turf and crustose coralline algae were very abundant along the transect. Cover of macroalgae and calcified 


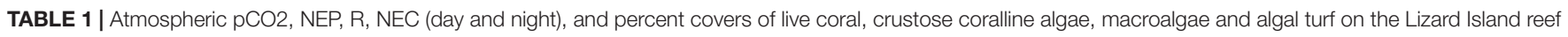
flat for past and the current studies.

\begin{tabular}{|c|c|c|c|c|c|c|c|}
\hline & Limer, 1976 & Kinsey, 1979 & $\begin{array}{c}\text { Pichon and } \\
\text { Morrissey, } 1981\end{array}$ & $\begin{array}{l}\text { Silverman } \\
\text { et al., } 2009\end{array}$ & $\begin{array}{l}\text { Silverman } \\
\text { et al., } 2009\end{array}$ & $\begin{array}{c}\text { This } \\
\text { study } 2016\end{array}$ & $\begin{array}{c}\text { This } \\
\text { study } 2018\end{array}$ \\
\hline Atmospheric pCO2 ( $\mu$ atm) & 331 & & & 386 & 387 & 401 & 406.9 \\
\hline $\mathrm{NEP}\left(\mathrm{mmol} \cdot \mathrm{m}^{-2} \cdot \mathrm{d}^{-1}\right)$ & & 50 & & & & $36.2 \pm 3.3$ & $-13.5 \pm 5.5$ \\
\hline$R\left(\mathrm{mmol} \cdot \mathrm{m}^{-2} \cdot \mathrm{d}^{-1}\right)$ & & -47 & & & & $-20.2 \pm 1.4$ & $-19.2 \pm 5.5$ \\
\hline $\mathrm{NEC}$ day $\left(\mathrm{mmol} \cdot \mathrm{m}^{-2} \cdot \mathrm{d}^{-1}\right)$ & $83-105$ & 83 & & $61 \pm 12$ & $54 \pm 13$ & $10.6 \pm 2.44$ & $34.8 \pm 18.6$ \\
\hline NEC night $\left(\mathrm{mmol} \cdot \mathrm{m}^{-2} \cdot \mathrm{d}^{-1}\right)$ & & & & $-19-11$ & $-57-38$ & & $12.3 \pm 9.9$ \\
\hline Coral & $15-10$ & $15-10$ & $8.0 \pm 5.6$ & $8.3 \pm 3.2$ & $7.1 \pm 1.5$ & $2.6 \pm 1.9$ & $8.2 \pm 0.7$ \\
\hline Calcified algae & & & & & & $4.2 \pm 2.3$ & $9.3 \pm 0.4$ \\
\hline Macroalgae & & & $11.9 \pm 1.8$ & & & $2.1 \pm 1.7$ & $2.5 \pm 0.3$ \\
\hline Algal turf & & & & & & $67 \pm 4.7$ & $43.3 \pm 1.4$ \\
\hline
\end{tabular}

Values are means, ranges, or means $\pm S E$.

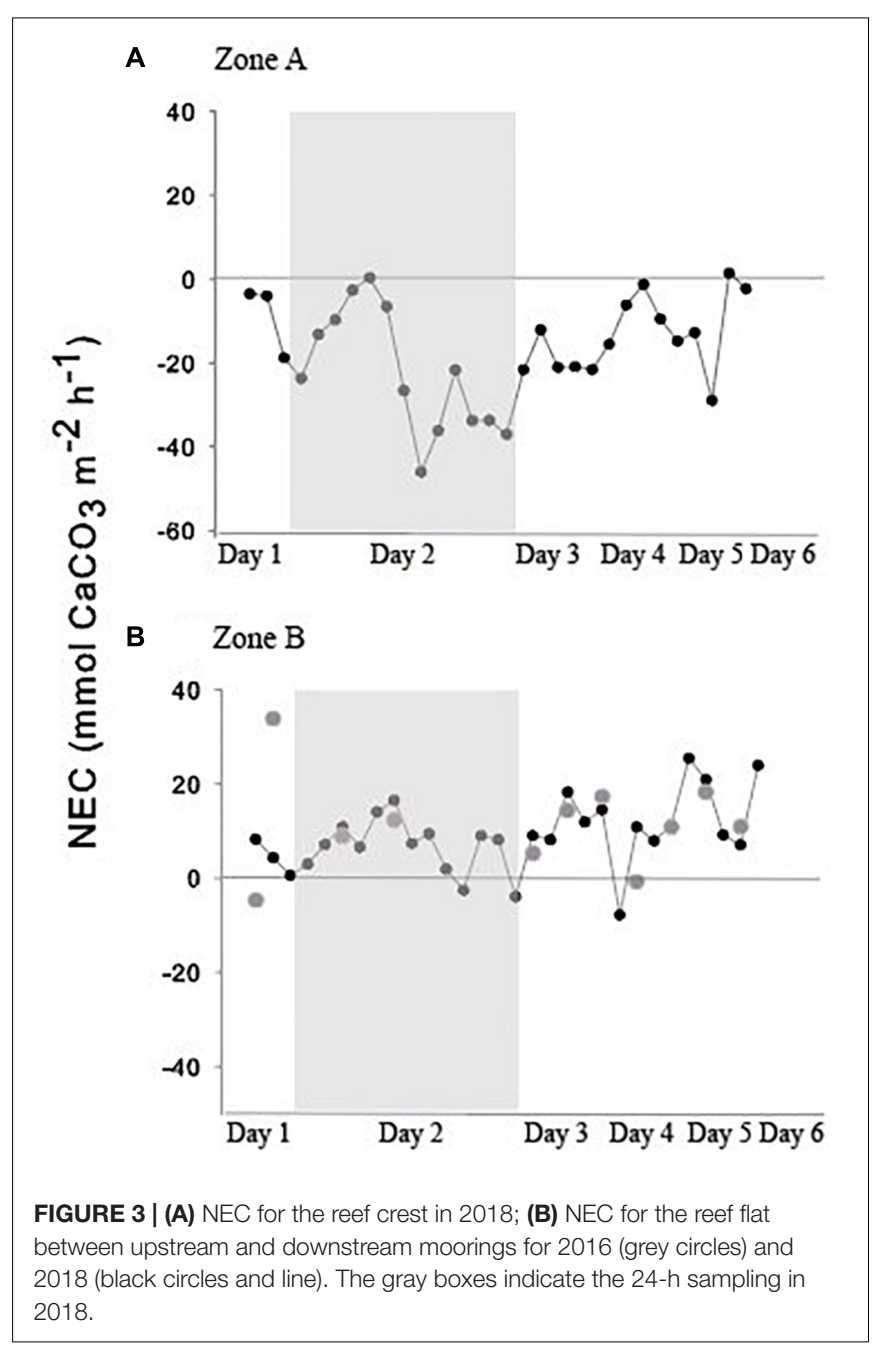

algae remained low at $2.2 \pm 0.3$ and $9.6 \pm 0.4$ respectively, while total live coral cover was higher compared to 2016, and was similar to values reported in the past for the same reef flat $(8.2 \pm 0.7)$ (Table 1).
TABLE 2 | Daytime and nighttime NEC in each reef zone on the Lizard Island reef flat during September 2018.

\begin{tabular}{lllc}
\hline & \multicolumn{1}{c}{ Zone A } & Zone B & Zone A + B \\
\hline & & & \\
NEC day $\left(\mathrm{mmol} \cdot \mathrm{m}^{-2} \cdot \mathrm{d}^{-1}\right)$ & $-29.1 \pm 20.9$ & $34.8 \pm 18.6$ & $5.32 \pm 23.04$ \\
NEC night $\left(\mathrm{mmol} \cdot \mathrm{m}^{-2} \cdot \mathrm{d}^{-1}\right)$ & $-49.6 \pm 106.01$ & $12.3 \pm 9.9$ & $-38.4 \pm 86.7$
\end{tabular}

The reef zones are: reef crest (Zone $A$ ), the reef flat (Zone B), and along the whole reef tract (Zone $A+B$ ). Values are means $\pm S E$.

\section{DISCUSSION}

This study measured NEP and NEC following two consecutive cyclones in 2014-2015, and the El Nino-driven mass bleaching events in 2016 and 2017 on a reef flat on Australia's GBR and documented changes in community function. While NEP measured in 2016 was similar to values reported in the 1970s (Kinsey, 1979), NEP measured in 2018 showed a decline. In 2016, NEC was depressed, compared to rates measured in 20082009 (Limer, 1976; Kinsey, 1979; Pichon and Morrissey, 1981; Silverman et al., 2014), but importantly, increased by a factor of 3 in 2018, perhaps as the result of increased abundances of live coral and calcified algae. Detecting changes in reef community metabolism over time often is complicated by a lack of baseline data, including data on changes in benthic community composition. This study leverages the availability of baseline data on organic and inorganic carbon production that have been quantified over the past four decades. The changes in community function associated with recent disturbances, and within the context of ongoing OA suggest that dissolution rates may have increased in the past decades causing a decline in NEC, especially at night. Importantly, increases in dissolution rates varied among different reef zones, with highest rates on the reef crest. While, this study did not directly investigate ocean acidification, the increase in dissolution observed here and past data (Silverman et al., 2014) suggest this ongoing press disturbance may have an effect on ecosystem function at the study site.

Rising seawater temperatures, cyclones, and ocean acidification are predicted to change coral reefs into new configurations in which the reef flats may no longer exist as 
calcifying entities, thus potentially losing many ecosystem goods and services (Hughes et al., 2017a). To better understand the response of coral reefs to environmental changes, it is critical to investigate the accumulated effects of both pulse and press disturbances on both community structure and function. Even though these disturbances operate on different time scales, they simultaneously have direct and indirect effects on reef community structure and function. Pulse disturbances such as bleaching and cyclones often result in high levels of mortality, especially among key habitat-forming reef organisms (Connell, 1997) and thereby indirectly affect community structure and function (Harmelin-Vivien, 1994). Importantly, the recovery (or lack thereof) from pulse disturbances occurs within the context of longer-term press disturbances such as ocean acidification and SST warming which also may cause mortality and further alter community structure and function (Connell et al., 1997; Wakeford et al., 2008; De'ath et al., 2009; Comeau et al., 2016). Studies investigating responses of coral reef flat communities to climate change usually focus either on the impact of bleaching [e.g., (Cantin et al., 2010; Frieler et al., 2013; Van Hooidonk et al., 2013)] or on ocean acidification [e.g., (Ricke et al., 2013)]. While the few studies that do combine both the impact of ocean acidification and increasing temperatures, have not linked the responses of NEP and NEC to these two disturbance drivers [e.g., (Guinotte et al., 2003; Buddemeier et al., 2008; Silverman et al., 2009)]. In particular, most studies often manipulate individual coral colonies and/or other calcifying organisms [e.g., (Grottoli et al., 2014; Schoepf et al., 2015)] without extending organism level responses to the community level, thus limiting our understanding of how these disturbances, and in particular bleaching, might affect community metabolism [but see (DeCarlo et al., 2017; Courtney et al., 2018)].

Press and pulse disturbances resulted in changes in NEP and R. R remained constant with similar values in 2016 and 2018. However, $\mathrm{R}$ measured here was lower than previous studies on reef flats at Lizard Island (Kinsey, 1979) likely as a result of lower biomass of benthic organisms associated with recent disturbances. The NEP values measured in 2016 were consistent with previous studies on reef flats at Lizard Island (Kinsey, 1979) and elsewhere (Albright et al., 2015; Shaw et al., 2015), indicating that gross production and respiration were roughly similar, and that the communities consume roughly the same amount of organic carbon as they produce (Atkinson, 2011). Conversely, NEP values measured in 2018 were lower, likely due to reduced abundance of algal turfs. Algal turfs are one of the most productive benthic components of many reefs (Odum and Odum, 1955) and can be affected by abiotic disturbances such as cyclones. In both years, benthic algae constituted the majority of the total benthic cover and therefore were the dominant component contributing to NEP. Maintaining NEP is critical because this process removes DIC from seawater, thus providing some short-term buffer for aragonite saturation. Furthermore, NEP and NEC are correlated in coral reef communities thus lower NEP may further suppress NEC (Gattuso et al., 1999; Shaw et al., 2012; Albright et al., 2015). There is compelling evidence that high CO2 may suppress primary productivity and favor net dissolution in calcifiers such as CCA (Anthony et al., 2008). However, more experimental manipulations would be needed to confirm this hypothesis on the studied reef flat.

Daytime NEC of the Lizard Island reef flat declined between 1976 and 2008-2009 (Limer, 1976; Kinsey, 1979; Silverman et al., 2014) and was reduced further between 2008-2009 and 2016. By 2018, daytime NEC of the reef flat had increased threefold (but still remained lower than values reported in 2008-2009) and was likely associated with an increase in live corals and a doubling of the abundance of calcified algae. It is possible that the high NEC rates were also a result of increased metabolism during the recovery from the two consecutive bleaching events as observed in Dongsha Atoll (DeCarlo et al., 2017), however, more studies before, during, and after bleaching events are needed.

NEC varied across reef zones with the lowest NEC measured on the reef crest where live cover of calcifiers (corals and algae) was low (authors personal observations). While the frequency of water sampling to quantify NEC differed between 2016 and 2018 (with more frequent sampling in 2018), it is unlikely that this would result in such large differences in rates of NEC. Similarly, variation in NEC between years/decades likely is not due to seasonal variability, as all measurement were made during the same season. Apparent total live coral cover remained overall stable at $\sim 8 \%$ in the last decade thus suggesting that non-biotic components of the reef (i.e., sediments and carbonate pavement) may have also played a big role in the observed decline in NEC at the community level.

Nighttime measurements of NEC were similar to those reported previously (Limer, 1976; Silverman et al., 2014) indicating dissolution has not increased on this reef over the past four decades, despite an ongoing decrease in $\mathrm{pH}$ due to OA. Nighttime dissolution on reef flats generally is attributed to processes occurring primarily within the carbonate sediments (Santos et al., 2011; Eyre et al., 2014). Dissolution of sediments can occur even when the overlying seawater is supersaturated with respect to aragonite, due to respiration of organic matter within the sediment (Andersson and Gledhill, 2013). Such microbial activity reduces $\mathrm{pH}$ as the result of microbial respiration, creating conditions that enhance carbonate dissolution.

There is increasing evidence on the effects of disturbances and changes in community structure on ecosystem function (Alvarez-Filip et al., 2009, 2011, 2013; Carricart-Ganivet et al., 2012). Disturbances have selective effects on coral assemblages and taxonomic differences contribute to changes in community structure (Done, 1999; Loya et al., 2001). Shifts in coral assemblages may not ensure maintenance of community function (Alvarez-Filip et al., 2013). For instance, changes to coral composition may cause mortality of fish and invertebrates directly relying on corals for food and shelter (Stella et al., 2010, 2011; Pratchett et al., 2011; Richardson et al., 2018). Shifts in coral assemblages also have resulted in declines in reef spatial complexity and calcification (Alvarez-Filip et al., 2009, 2011, 2013; Carricart-Ganivet et al., 2012). These declines suggest that some reefs may not display vertical accretion rates sufficient to keep pace with projected rates of global sea-level rise (Perry et al., 2012). 
Overall reef accretion (carbonate accumulation and vertical growth) is a balance between $\mathrm{CaCO}_{3}$ precipitation, dissolution, and physical and biological erosion. It is important to consider that for coral reefs to persist, the rate of diel $\mathrm{CaCO}_{3}$ production must be higher than the diel rate of dissolution to ensure that gross calcification is greater than dissolution and physical damage (Hoegh-Guldberg et al., 2007). NEC for the entire reef transect (reef crest + reef flat) indicates a net balance that may not support continued accretion under current conditions. While coral reefs worldwide are exposed to the long-term perturbation of OA (over multiple decades to centuries), shorter-term pulse disturbances will magnify the challenges for calcifiers on coral reefs. Coral mortality due to bleaching reduces calcification and alters the ratio between net calcification and dissolution, and thus poses a severe threat to reef persistence over shorter times scales (years-decades). Importantly, the high dissolution rates on the reef crest may challenge this section of the reef which may be severely subject to erosion as consequence of sea level rise (Storlazzi et al., 2011).

This study compared changes in reef function over shorter time scales than changes previously documented over decades. While community function can recover following major pulse disturbances such as bleaching (Courtney et al., 2018), the degree to which coral reef function recovers will depend upon disturbance regime. With increasing frequency and severity of mass bleaching events and cyclones and the ongoing (slower acting) stress of $\mathrm{OA}$, the persistence of the reef flat as a calcifying entity may be jeopardized. Long-term measurements of both reef community structure and function are needed to facilitate predictions of the trajectories of the responses of coral reef ecosystems in a future warmer and more acidic ocean.

\section{REFERENCES}

Albright, R., Benthuysen, J., Cantin, N., Caldeira, K., and Anthony, K. (2015). Coral reef metabolism and carbon chemistry dynamics of a coral reef flat. Geophys. Res. Lett. 42, 3980-3988. doi: 10.1002/2015gl063488

Albright, R., Caldeira, L., Hosfelt, J., Kwiatkowski, L., Maclaren, J. K., Mason, B. M., et al. (2016). Reversal of ocean acidification enhances net coral reef calcification. Nature 531, 362-365. doi: 10.1038/nature17155

Alvarez-Filip, L., Carricart-Ganivet, J. P., Horta-Puga, G., and Iglesias-Prieto, R. (2013). Shifts in coral-assemblage composition do not ensure persistence of reef functionality. Sci. Rep. 3:3486. doi: 10.1038/srep03486

Alvarez-Filip, L., Dulvy, N. K., Côté, I. M., Watkinson, A. R., and Gill, J. A. (2011). Coral identity underpins architectural complexity on Caribbean reefs. Ecol. Appl. 21, 2223-2231. doi: 10.1890/10-1563.1

Alvarez-Filip, L., Dulvy, N. K., Gill, J. A., Côté, I. M., and Watkinson, A. R. (2009). Flattening of Caribbean coral reefs: region-wide declines in architectural complexity. Proc. R. Soc. B Biol. Sci. 276, 3019-3025. doi: 10.1098/rspb.2009. 0339

Andersson, A. J., and Gledhill, D. (2013). Ocean acidification and coral reefs: effects on breakdown, dissolution, and net ecosystem calcification. Annu. Rev. Mar. Sci. 5, 321-348. doi: 10.1146/annurev-marine-121211-172241

Andersson, A. J., and Mackenzie, F. T. (2004). Shallow-water oceans: a source or sink of atmospheric CO2? Front. Ecol. Environ. 2, 348-353. doi: 10.1890/15409295(2004)002\%5B0348:soasos\%5D2.0.co;2

Andersson, A. J., Yeakel, K. L., Bates, N. R., and De Putron, S. J. (2014). Partial offsets in ocean acidification from changing coral reef biogeochemistry. Nat. Clim. Change 4, 56-61. doi: 10.1038/nclimate2050

\section{DATA AVAILABILITY}

The datasets for this study can be found in the SeaBASS NASA Repository (https://seabass.gsfc.nasa.gov/experiment/CORAL).

\section{AUTHOR CONTRIBUTIONS}

$\mathrm{CP}, \mathrm{RC}$, and $\mathrm{EH}$ designed the study. $\mathrm{CP}$ and $\mathrm{RC}$ collected the data and wrote the manuscript. CP analyzed the data. All authors contributed to the final text and figures.

\section{FUNDING}

This study is a contribution from the National Aeronautics and Space Administration (NASA) Jet Propulsion Laboratory (JPL) Grant NNX16AB05G awarded to EH, (https://coral.jpl. nasa.gov) and from the Lizard Island Postdoctoral fellowship 2018-2019 from the Australian Museum awarded to CP. CP gratefully thanks the Lizard Island Postdoctoral fellowship for the support. This study is a contribution 294 from the CSUN Marine Biology Program.

\section{ACKNOWLEDGMENTS}

The authors are grateful to the staff at the Lizard Island Research Station for logistic support, S. Ginther for the help with data collection, S. Peltier (BIOS) for analysis of the benthic photomosaics, M. Ho for invaluable field assistance, and S. Doo for the help with titrations.

Anthony, K. R., Kline, D. I., Diaz-Pulido, G., Dove, S., and Hoegh-Guldberg, O. (2008). Ocean acidification causes bleaching and productivity loss in coral reef builders. Proc. Natl. Acad. Sci. U.S.A. 105, 17442-17446. doi: 10.1073/pnas. 0804478105

Atkinson, M. J. (2011). “Biogeochemistry of nutrients," in Coral Reefs: An Ecosystem in Transition, eds Z. Dubinsky, and N. Stambler (Netherlands: Springer), 199-206. doi: 10.1007/978-94-007-0114-4_13

Barnes, D. J. (1983). Profiling coral reef productivity and calcification using $\mathrm{pH}$ and oxygen electrodes. J. Exp. Mar. Biol. Ecol. 66, 149-161. doi: 10.1016/00220981(83)90036-9

Benson, B. B., and Krause, D. (1984). The concentration and isotopic fractionation of oxygen dissolved in freshwater and seawater in equilibrium with the atmosphere. Limnol. Oceanogr. 29, 620-632. doi: 10.4319/lo.1984.29.3.0620

Buddemeier, R. W., Jokiel, P. L., Zimmerman, K. M., Lane, D. R., Carey, J. M., Bohling, G. C., et al. (2008). A modeling tool to evaluate regional coral reef responses to changes in climate and ocean chemistry. Limnol. Oceanogr. Methods 6, 395-411. doi: 10.4319/lom.2008.6.395

Cantin, N. E., Cohen, A. L., Karnauskas, K. B., Tarrant, A. M., and McCorkle, D. C. (2010). Ocean warming slows coral growth in the central Red Sea. Science 329, 322-325. doi: 10.1126/science.1190182

Carricart-Ganivet, J. P., Cabanillas-Teran, N., Cruz-Ortega, I., and Blanchon, P. (2012). Sensitivity of calcification to thermal stress varies among genera of massive reef-building corals. PLoS One 7:e32859. doi: 10.1371/journal.pone. 0032859

Comeau, S., Carpenter, R. C., Lantz, C. A., and Edmunds, P. J. (2015). Ocean acidification accelerates dissolution of experimental coral reef communities. Biogeosciences 12, 365-372. doi: 10.5194/bg-12-365-2015 
Comeau, S., Edmunds, P. J., Spindel, N. B., and Carpenter, R. C. (2013). The responses of eight coral reef calcifiers to increasing partial pressure of $\mathrm{CO} 2$ do not exhibit a tipping point. Limnol. Oceanogr. 58, 388-398. doi: 10.4319/lo. 2013.58.1.0388

Comeau, S., Lantz, C. A., Edmunds, P. J., and Carpenter, R. C. (2016). Framework of barrier reefs threatened by ocean acidification. Glob. Change Biol. 22, 12251234. doi: $10.1111 /$ gcb.13023

Connell, J. H. (1997). Disturbance and recovery of coral assemblages. Coral Reefs 16, S101-S113.

Connell, J. H., Hughes, T. P., and Wallace, C. C. (1997). A 30-year study of coral abundance, recruitment, and disturbance at several scales in space and time. Ecol. Monogr. 67, 461-488. doi: 10.1890/0012-9615(1997)067\%5B0461: aysoca $\% 5 \mathrm{D} 2.0 . \mathrm{co} ; 2$

Cooper, T. F., De'Ath, G., Fabricius, K. E., and Lough, J. M. (2008). Declining coral calcification in massive Porites in two nearshore regions of the northern Great Barrier Reef. Glob. Change Biol. 14, 529-538. doi: 10.1111/j.1365-2486.2007. 01520.x

Courtney, T. A., De Carlo, E. H., Page, H. N., Bahr, K. D., Barro, A., Howins, N., et al. (2018). Recovery of reef-scale calcification following a bleaching event in Kāne’ohe Bay. Hawai'i. Limnol. Oceanogr. Lett. 3, 1-9. doi: 10.1002/lol2.10056

De'ath, G., Fabricius, K. E., Sweatman, H., and Puotinen, M. (2012). The 27-year decline of coral cover on the Great Barrier Reef and its causes. Proc. Natl. Acad. Sci. U.S.A. 109, 17995-17999. doi: 10.1073/pnas.1208909109

De'ath, G., Lough, J. M., and Fabricius, K. E. (2009). Declining coral calcification on the Great Barrier Reef. Science 323, 116-119. doi: 10.1126/science.1165283

DeCarlo, T. M., Cohen, A. L., Wong, G. T., Shiah, F.-K., Lentz, S. J., Davis, K. A., et al. (2017). Community production modulates coral reef $\mathrm{pH}$ and the sensitivity of ecosystem calcification to ocean acidification. J. Geophys. Res. Oceans 122, 745-761. doi: 10.1002/2016jc012326

Dickson, A. G., Sabine, C. L., Christian, J. R. (eds). (2007). “Guide to best practices for ocean CO2 measurements," in Sidney, British Columbia, North Pacific Marine Science Organization (Ostend: PICES Special Publication 3), 191.

Done, T. J. (1999). Coral community adaptability to environmental change at the scales of regions, reefs and reef zones. Am. Zool. 39, 66-79. doi: 10.1093/icb/39. 1.66

Done, T. J., Dayton, P. K., Dayton, A. E., and Steger, R. (1991). Regional and local variability in recovery of shallow coral communities: Moorea, French Polynesia and central Great Barrier Reef. Coral Reefs 9, 183-192. doi: 10.1007/bf0029 0420

Dove, S. G., Kline, D. I., Pantos, O., Angly, F. E., Tyson, G. W., and HoeghGuldberg, O. (2013). Future reef decalcification under a business-as-usual CO2 emission scenario. Proc. Natl. Acad. Sci. U.S.A. 110, 15342-15347. doi: 10.1073/ pnas. 1302701110

Edmunds, P. J. (2002). Long-term dynamics of coral reefs in St. John, US Virgin Islands. Coral Reefs 21, 357-367.

Edmunds, P. J., Comeau, S., Lantz, C., Andersson, A., Briggs, C., Cohen, A., et al. (2016). Integrating the effects of ocean acidification across functional scales on tropical coral reefs. Bioscience 66, 350-362. doi: 10.1093/biosci/biw023

Eyre, B. D., Andersson, A. J., and Cyronak, T. (2014). Benthic coral reef calcium carbonate dissolution in an acidifying ocean. Nat. Clim. Change 4, 969-976. doi: $10.1038 /$ nclimate 2380

Frieler, K., Meinshausen, M., Golly, A., Mengel, M., Lebek, K., Donner, S. D., et al. (2013). Limiting global warming to $2^{\circ} \mathrm{C}$ is unlikely to save most coral reefs. Nat. Clim. Change 3, 165-170. doi: 10.1038/nclimate1674

Gardner, T. A., Côté, I. M., Gill, J. A., Grant, A., and Watkinson, A. R. (2003). Long-term region-wide declines in Caribbean corals. Science 301, 958-960. doi: 10.1126/science.1086050

Gattuso, J.-P., Allemand, D., and Frankignoulle, M. (1999). Photosynthesis and calcification at cellular, organismal and community levels in coral reefs: a review on interactions and control by carbonate chemistry. Am. Zool. 39, 160-183. doi: 10.1093/icb/39.1.160

Gaylord, B., Kroeker, K. J., Sunday, J. M., Anderson, K. M., Barry, J. P., Brown, N. E., et al. (2015). Ocean acidification through the lens of ecological theory. Ecology 96, 3-15. doi: 10.1890/14-0802.1

Grottoli, A. G., Warner, M. E., Levas, S. J., Aschaffenburg, M. D., Schoepf, V., McGinley, M., et al. (2014). The cumulative impact of annual coral bleaching can turn some coral species winners into losers. Glob. Change Biol. 20, 38233833. doi: $10.1111 / \mathrm{gcb} .12658$
Guinotte, J. M., Buddemeier, R. W., and Kleypas, J. A. (2003). Future coral reef habitat marginality: temporal and spatial effects of climate change in the Pacific basin. Coral Reefs 22, 551-558. doi: 10.1007/s00338-003-0331-4

Halford, A., Cheal, A. J., Ryan, D., and Williams, D. M. (2004). Resilience to large-scale disturbance in coral and fish assemblages on the Great Barrier Reef. Ecology 85, 1892-1905. doi: 10.1890/03-4017

Harmelin-Vivien, M. L. (1994). The effects of storms and cyclones on coral reefs: a review. J. Coast. Res. 12, 211-231. doi: 10.1111/nyas.13322

Hatcher, B. G. (1997). Coral reef ecosystems: how much greater is the whole than the sum of the parts? Coral Reefs 16, S77-S91.

Hoegh-Guldberg, O. (1999). Climate change, coral bleaching and the future of the world's coral reefs. Mar. Freshw. Res. 50, 839-866.

Hoegh-Guldberg, O., Mumby, P. J., Hooten, A. J., Steneck, R. S., Greenfield, P., Gomez, E., et al. (2007). Coral reefs under rapid climate change and ocean acidification. Science 318, 1737-1742.

Hughes, T. P., Barnes, M. L., Bellwood, D. R., Cinner, J. E., Cumming, G. S., Jackson, J. B., et al. (2017a). Coral reefs in the Anthropocene. Nature 546, 82-90.

Hughes, T. P., Kerry, J. T., Álvarez-Noriega, M., Álvarez-Romero, J. G., Anderson, K. D., Baird, A. H., et al. (2017b). Global warming and recurrent mass bleaching of corals. Nature 543, 373-377. doi: 10.1038/nature2 1707

Hughes, T. P., Rodrigues, M. J., Bellwood, D. R., Ceccarelli, D., Hoegh-Guldberg, O., McCook, L., et al. (2007). Phase shifts, herbivory, and the resilience of coral reefs to climate change. Curr. Biol. 17, 360-365. doi: 10.1016/j.cub.2006.12.049

Kayanne, H., Hata, H., Kudo, S., Yamano, H., Watanabe, A., Ikeda, Y., et al. (2005). Seasonal and bleaching-induced changes in coral reef metabolism and $\mathrm{CO} 2 \mathrm{flux}$. Glob. Biogeochem. Cycles 19:GB3015.

Kinsey, D. W. (1979). Carbon Turnover and Accumulation by Coral Reefs. Ph. D. thesis, University of Hawaii at Manoa, Honolulu, HI.

Kleypas, J. A., Buddemeier, R. W., Archer, D., Gattuso, J.-P., Langdon, C., and Opdyke, B. N. (1999). Geochemical consequences of increased atmospheric carbon dioxide on coral reefs. Science 284, 118-120. doi: 10.1126/science.284. 5411.118

Kuffner, I. B., Andersson, A. J., Jokiel, P. L., Ku'ulei, S. R., and Mackenzie, F. T. (2008). Decreased abundance of crustose coralline algae due to ocean acidification. Nat. Geosci. 1, 114-117. doi: 10.1038/ngeo100

Langdon, C., Broecker, W. S., Hammond, D. E., Glenn, E., Fitzsimmons, K., Nelson, S. G., et al. (2003). Effect of elevated CO2 on the community metabolism of an experimental coral reef. Glob. Biogeochem. Cycles 17:1011.

Langdon, C., Gattuso, J.-P., and Andersson, A. (2010). Measurements of Calcification and Dissolution of Benthic Organisms and 13 Communities. Available at: https://www.researchgate.net/profile/Chris_Langdon/publication/ 232707477_Measurements_of_calcification_and_dissolution_of_benthic_ organisms_and_communities/links/02e7e529fb4fe672c9000000.pdf (accessed April 12, 2017).

Limer, E. (1976). Metabolic processes of coral reef communities at Lizard Island, Quuensland. Search 7, 463-468.

Loya, Y., Sakai, K., Yamazato, K., Nakano, Y., Sambali, H., and van Woesik, R. (2001). Coral bleaching: the winners and the losers. Ecol. Lett. 4, 122-131. doi: 10.1046/j.1461-0248.2001.00203.x

Madin, J. S., Baird, A. H., Bridge, T. C., Connolly, S. R., Zawada, K. J., and Dornelas, M. (2018). Cumulative effects of cyclones and bleaching on coral cover and species richness at Lizard Island. Mar. Ecol. Prog. Ser. 604, 263-268. doi: 10. 3354/meps12735 doi: 10.3354/meps12735Madin et al., 2018; Smokorowski and Randall, 2017.)

McMahon, A., Santos, I. R., Schulz, K. G., Scott, A., Silverman, J., Davis, K. L., et al. (2019). Coral reef calcification and production after the 2016 bleaching event at Lizard Island, Great Barrier Reef. J. Geophys. Res. Oceans 124, 4003-4016.

Melillo, J. M., McGuire, A. D., Kicklighter, D. W., Moore, B., Vorosmarty, C. J., and Schloss, A. L. (1993). Global climate change and terrestrial net primary production. Nature 363, 234-240. doi: 10.1038/363234a0

Nemani, R. R., Keeling, C. D., Hashimoto, H., Jolly, W. M., Piper, S. C., Tucker, C. J., et al. (2003). Climate-driven increases in global terrestrial net primary production from 1982 to 1999. Science 300, 1560-1563. doi: 10.1126/science. 1082750

Norström, A. V., Nyström, M., Lokrantz, J., and Folke, C. (2009). Alternative states on coral reefs: beyond coral-macroalgal phase shifts. Mar. Ecol. Prog. Ser. 376, 295-306. doi: 10.1073/pnas.0802812105 
Nyström, M., and Folke, C. (2001). Spatial resilience of coral reefs. Ecosystems 4, 406-417. doi: 10.1007/s10021-001-0019-y

Odum, H. T., and Odum, E. P. (1955). Trophic structure and productivity of a windward coral reef community on Eniwetok Atoll. Ecol. Monogr. 25, 291-320. doi: $10.2307 / 1943285$

Perry, C. T., Edinger, E. N., Kench, P. S., Murphy, G. N., Smithers, S. G., Steneck, R. S., et al. (2012). Estimating rates of biologically driven coral reef framework production and erosion: a new census-based carbonate budget methodology and applications to the reefs of Bonaire. Coral Reefs 31, 853-868. doi: 10.1007/ s00338-012-0901-4

Pichon, M., and Morrissey, J. (1981). Benthic zonation and community structure of south island reef, Lizard Island (Great Barrier Reef). Bull. Mar. Sci. 31, 581-593.

Pisapia, C., Burn, D., Yoosuf, R., Najeeb, A., Anderson, K. D., and Pratchett, M. S. (2016). Coral recovery in the central Maldives archipelago since the last major mass-bleaching, in 1998. Sci. Rep. 6:34720. doi: 10.1038/srep34720

Pratchett, M. S., Hoey, A. S., Wilson, S. K., Messmer, V., and Graham, N. A. (2011). Changes in biodiversity and functioning of reef fish assemblages following coral bleaching and coral loss. Diversity 3, 424-452. doi: 10.1111/gcb.14119

Richardson, L. E., Graham, N. A., Pratchett, M. S., Eurich, J. G., and Hoey, A. S. (2018). Mass coral bleaching causes biotic homogenization of reef fish assemblages. Glob. Change Biol. 24, 3117-3129. doi: 10.1111/gcb.14119

Ricke, K. L., Orr, J. C., Schneider, K., and Caldeira, K. (2013). Risks to coral reefs from ocean carbonate chemistry changes in recent earth system model projections. Environ. Res. Lett. 8:034003. doi: 10.1088/1748-9326/8/3/034003

Russell, B. D., Harley, C. D., Wernberg, T., Mieszkowska, N., Widdicombe, S., HallSpencer, J. M., et al. (2011). Predicting Ecosystem Shifts Requires New Approaches that Integrate the Effects of Climate Change Across Entire Systems. London: The Royal Society.

Santos, I. R., Glud, R. N., Maher, D., Erler, D., and Eyre, B. D. (2011). Diel coral reef acidification driven by porewater advection in permeable carbonate sands, Heron Island, Great Barrier Reef. Geophys. Res. Lett. 38:L03604.

Schoepf, V., Grottoli, A. G., Levas, S. J., Aschaffenburg, M. D., Baumann, J. H., Matsui, Y., et al. (2015). Annual coral bleaching and the long-term recovery capacity of coral. Proc. R. Soc. 282:20151887. doi: 10.1098/rspb.2015.1887

Shamberger, K. E. F., Feely, R. A., Sabine, C. L., Atkinson, M. J., DeCarlo, E. H., Mackenzie, F. T., et al. (2011). Calcification and organic production on a Hawaiian coral reef. Mar. Chem. 127, 64-75. doi: 10.1016/j.marchem.2011.08. 003

Shaw, E. C., McNeil, B. I., and Tilbrook, B. (2012). Impacts of ocean acidification in naturally variable coral reef flat ecosystems. J. Geophys. Res. Oceans 117:C03038.

Shaw, E. C., Phinn, S. R., Tilbrook, B., and Steven, A. (2015). Natural in situ relationships suggest coral reef calcium carbonate production will decline with ocean acidification. Limnol. Oceanogr. 60, 777-788. doi: 10.1002/lno.10048

Silverman, J., Lazar, B., Cao, L., Caldeira, K., and Erez, J. (2009). Coral reefs may start dissolving when atmospheric CO2 doubles. Geophys. Res. Lett. 36:L05606.
Silverman, J., Schneider, K., Kline, D. I., Rivlin, T., Rivlin, A., Hamylton, S., et al. (2014). Community calcification in Lizard Island, Great Barrier Reef: a 33year perspective. Geochim. Cosmochim. Acta 144, 72-81. doi: 10.1016/j.gca.2014.09. 011

Smith, S. V., and Buddemeier, R. W. (1992). Global change and coral reef ecosystems. Annu. Rev. Ecol. Syst. 23, 89-118. doi: 10.1146/annurev.ecolsys. 23.1.89

Smith, S. V., and Kinsey, D. W. (1978). Calcification and organic carbon metabolism as indicated by carbon dioxide. Coral Reefs Res. Methods 5, 469484. doi: 10.1111/j.1365-294X.2012.05554.x

Smokorowski, K. E., and Randall, R. G. (2017). Cautions on using the Before-AfterControl-Impact design in environmental effects monitoring programs. Facets 2 , 212-232. doi: 10.1139/facets-2016-0058

Stella, J. S., Jones, G. P., and Pratchett, M. S. (2010). Variation in the structure of epifaunal invertebrate assemblages among coral hosts. Coral Reefs 29, 957-973. doi: 10.1007/s00338-010-0648-8

Stella, J. S., Munday, P. L., and Jones, G. P. (2011). Effects of coral bleaching on the obligate coral-dwelling crab Trapezia cymodoce. Coral Reefs 30, 719-727. doi: 10.1007/s00338-011-0748-0

Storlazzi, C. D., Elias, E., Field, M. E., and Presto, M. K. (2011). Numerical modeling of the impact of sea-level rise on fringing coral reef hydrodynamics and sediment transport. Coral Reefs 30, 83-96. doi: 10.1007/s00338-0110723-9

Takeshita, Y., McGillis, W., Briggs, E. M., Carter, A. L., Donham, E. M., Martz, T. R., et al. (2016). Assessment of net community production and calcification of a coral reef using a boundary layer approach. J. Geophys. Res. Oceans 121, 5655-5671. doi: 10.1002/2016jc01 1886

Van Hooidonk, R., Maynard, J. A., and Planes, S. (2013). Temporary refugia for coral reefs in a warming world. Nat. Clim. Change 3, 508-511. doi: 10.1038/ nclimate 1829

Wakeford, M., Done, T. J., and Johnson, C. R. (2008). Decadal trends in a coral community and evidence of changed disturbance regime. Coral Reefs 27, 1-13. doi: 10.1007/s00338-007-0284-0

Conflict of Interest Statement: The authors declare that the research was conducted in the absence of any commercial or financial relationships that could be construed as a potential conflict of interest.

Copyright (c) 2019 Pisapia, Hochberg and Carpenter. This is an open-access article distributed under the terms of the Creative Commons Attribution License (CC BY). The use, distribution or reproduction in other forums is permitted, provided the original author(s) and the copyright owner(s) are credited and that the original publication in this journal is cited, in accordance with accepted academic practice. No use, distribution or reproduction is permitted which does not comply with these terms. 